\title{
Participatory work with young children: the trouble and transformation of age-based hierarchies
}

\author{
Caralyn Blaisdell
}

School of Education, University of Strathclyde, Glasgow, Scotland

Lord Hope Building Level 5

141 St. James Road

Glasgow G4 0LT

Email: caralyn.blaisdell@strath.ac.uk

Telephone: 01414448322

\section{Abstract}

This paper explores the ways that participatory work with young children was actually lived in practice, in one early childhood setting. Drawing on an ethnographic study, the paper argues that disruption of age-based hierarchy was key for making space and time for young children's meaningful participation. Practitioners held a strong, nuanced view of young children's 'richness', rather than defining young children in terms of what they lack. The finished state of adulthood was troubled, with adults seen as fellow 'emergent becomings', in the process of learning alongside children. However, despite conscious efforts to deconstruct age-based hierarchy, age and life experience remained troublesome concepts at the nursery. The paper examines tensions and limitations in how far adults were willing to cede control to young children, focusing on the example of care routines. The paper contends that participatory work with children must itself be maintained as a space for inquiry and reflection.

Keywords: children's participation, early childhood, child-adult relations, intergenerational relations, hierarchy, ethnography 


\section{Introduction}

Children's participation can usefully be understood as a measure of their 'presence' in society, culture, and community:

By presence, I mean the degree to which the voice, contribution and agency of the child is acknowledged in their many relationships.

$[\ldots]$ it is not enough to have a voice; it is equally important to also be heard in order for one to have a presence in society.

(Moosa-Mitha 2005, 381)

Participatory work, which seeks to enable a strong 'presence' for children and young people, has become popular in research, theory and practice. However, despite a variety of participatory activities on local, national, and international levels, a 'familiar list of challenges' remains - including tokenism, one-off opportunities for children to be involved, issues of inclusion/exclusion, and a failure to make participatory work an enduring part of organisational culture (Tisdall 2013). One reason for this difficulty in moving from rhetoric to meaningful practice is that participatory work with children and young people challenges dominant views of children as developing, vulnerable, and dependent — not yet adults, and therefore not full members of society (Tisdall 2015). If this is true for children and young people's participation generally, it is particularly so for young children, who may be viewed as 'pre-social' (Alderson, Hawthorne, and Killen 2005, 33) and 'too innocent and/or immature to participate meaningfully' (MacNaughton, Hughes, and Smith 2007, 164).

Strong advocacy for children's participation has, at times, involved sharply dichotomised thinking about adults and children. Mannion (2007, 413), for example, argues that there has often been a narrative of 'adults-as-oppressors vs. children-as- 
resisters' in the children's participation literature. Alternatively, some literature has left adults out of the frame completely, demonstrating 'how children have constructed their own spaces and practices as agents of their own destiny' (Mannion 2007, 413). Both of these scenarios, Mannion claims, fail to examine the adult dimension of children's participation in any depth. By keeping adults in the analytical frame, researchers can come to a more nuanced understanding of how children's place in the world is conceptualised, and what implications that may hold for their participation (Mannion 2007; Wyness 2015).

This paper explores the ways that participatory work with young children was lived and experienced in one early childhood setting, focusing on spatial, temporal and material practices. This spatial orientation forms a useful foundation for unpacking how childhood and adulthood were constructed and 'lived' at the setting, with a focus on the transformation of hierarchies. The paper begins by tracing key themes in the literature on participatory work with children and young people, focusing in particular on the ways that (early) childhood and adulthood are understood and set apart from one another. The paper then moves on to discuss the research methodology and empirical findings of the study.

\section{Participatory work with children and young people - the importance of child-adult relationships}

Child-adult relationships are a key factor that shape how children's participation is lived and experienced. Looking broadly, the biosocial process of 'generationing' that sets children apart from adults is one of hierarchy and subordination. In the UK context, Mayall (2002, 2006a, 2006b) claims that children are rarely seen as social contributors, indicating lower social status for children as a social group as compared to adults. A singularly 'gloomy view' of adults exercising power over children (Gallagher 2005) is 
not particularly helpful - power in generational relationships has more usefully been conceptualised as fluid, shifting, and incorporating children's agency and resistance (e.g. Gallagher, 2008; Corsaro, 2014; Esser et al., 2016; Leonard, 2016; Oswell, 2016). However, in terms of broader social patterning, children do occupy a subordinate position to adults, which manifests in material life experiences (Leonard 2016). This is particularly the case in institutional spaces, such as schools and nurseries, where daily life is structured by adult control and concerns about socialisation (Holloway and Valentine 2000; Harden 2012).

Children's contributions to social life are often overlooked because of 'adultist' norms that view childhood as 'not-adult', and therefore not a 'real' time in the lifecourse (Moosa-Mitha 2005). Or, children's contributions may only be recognised when to do so suits organisational purposes and timetables (Malone and Hartung 2010; Percy-Smith 2010). Due to children's subordinate position, the extent to which children's participation is recognised and valued is largely down to adult judgement. Le Borgne and Tisdall $(2017,123)$, for example, argue that adults' perception of children's competence can act as a 'threshold criterion'—with children who are judged incompetent 'not allowed or not supported to participate'.

Turning to early childhood, young children's 'presence'-the acknowledgement of their voice, contribution and agency--remains very limited; it is more accurate to speak of young children's absence from discussions that directly affect them, rather than their 'presence'. From a rights-based perspective, young children-defined by the UN Committee on the Rights of the Child (2005) as children under the age of eight yearsare entitled to all of the rights enshrined in the UN Convention on the Rights of the Child (1989). However, the UNCRC itself introduces the issue of age in entitlements to civil and political rights, as found in Article 12: that the views of the child should be 
'given due weight in accordance with the age and maturity of the child'. Despite this clause mentioning age and maturity, the Committee on the Rights of the Child have discouraged the creation of age limits that would restrict young children's Article 12 rights.

Alderson $(2008,142)$ reflects on some of the 'deeply held feelings' that may lead to a neglect of young children's participation rights. Among others, she lists:

- Confidence in adults' superior knowledge and good sense;

- Mistrust and a sense that young children cannot understand much, or give reliable accounts, or think sensibly;

- Deep concern about children's vulnerability;

- Anxiety that children are volatile, self-centred, and a potential danger to themselves and others

(Alderson 2008, 141)

Alderson $(2008,141)$ also suggests some of the feelings that may lead to adults being in favour of consulting with young children, including: trust in young children's ability to think creatively, enjoyment and excitement in working cooperatively with young children, and confidence that participation is vital and rewarding. She argues that rather than being a clear-cut issue, people tend to have mixed feelings about young children's participation rights - the balance of which may affect how young children are treated in various circumstances.

Though young children's participation is often 'overlooked or rejected' (UN Committee on the Rights of the Child 2005, para. 14), there is a growing body of work regarding children's participation in the early childhood context. For example, MacNaughton and others (2008) conceptualise young children as 'active citizens', 
compiling practical examples of how policymakers and educators might go about consulting young children about decisions that affect them, in accordance with the UNCRC. Lansdown (2005a, 2005b) has also focused on young children's participation rights, as has Alderson (Alderson, Hawthorne, and Killen 2005; 2008, 2010, 2012). Much of the literature on young children's participation focuses on their experiences in early learning and childcare settings ${ }^{1}$. For example, the influential Mosaic Approach straddles research and practice, describing methodology for consultation with young children in early years settings and beyond (Clark and Statham 2005, Clark et al. 2005, Clark 2007, Clark and Moss 2011).

Other researchers working in early learning and childcare contexts have focused on interactions between teachers and children, and how these interactions influence children's daily experiences. Bae (2012), for example, adopts the metaphor of 'spacious' interactions in which children's contributions are recognised in a variety of ways - through playfulness, questioning, space for imperfection, and dialogue in which teachers and children interpret and re-interpret each other's communications. Emilson and Folkesson (2006) similarly note the need for teachers to relax control in order to make space for young children's contributions. Ghirotto and Mazzoni (2014) suggest that early childhood teachers could use their powerful position in the playroom as a positive force, to highlight and facilitate children's own ideas. However, Johansson and Emilson (2010) warn against turning young children's participation into an ideologynoting that young children are indeed competent, but also vulnerable (as are all

${ }^{1}$ Terminology around early childhood education is subject to ongoing debate (Moss 2017). This paper uses the term 'early learning and childcare', recently adopted in Scotland (The Scottish Government 2014). 
community members). If children are required to be engaged and compliant (as judged by adults) in order to 'participate', surely this represents a clash between ideals and practice (e.g. Gallacher and Gallagher, 2008). Ferholt and Rainio (2016) note that ambivalence about engagement with classroom practices can be an important component of children's evolving feelings of personal engagement. However, young children's complex subjectivities are often ignored in favour of 'technocratic' practices in early years - trends which reduce the pedagogical space for children's participation (Bath and Karlsson 2016; Simpson et al. 2017).

As these examples illustrate, institutional practices (in early childhood and beyond) are shaped by how adulthood and childhood are positioned. Beliefs about adults/children and adulthood/childhood in turn shape the ways that children's participation is made real—creating opportunities, negotiations, and limitations. This paper particularly attends to how children's participation is 'imbued with a sense of spatiality' (e.g. Holloway and Pimlott-Wilson 2011, 13), lived in terms of spatial, temporal, and material practices. As Kraftl and others (2012b, 9) argue, 'relationships, rules and conflicts' within spaces can give insight into underlying norms and structures around childhoods. These insights tell us about how childhood is 'placed' (Kraftl, Horton, and Tucker 2012a) in policy and how that positioning is appropriated, resisted, and changed in actual daily practice.

\section{Research Methodology}

This paper draws on an ethnographic study, carried out in one early learning and childcare setting in Scotland — referred to as 'Castle Nursery'. The purpose of the study was to investigate how children's participation was 'lived' and negotiated in an early learning and childcare setting, with a focus on child-practitioner relationships. Castle 
Nursery was chosen for the fieldwork because children's participation was firmly on the agenda. Practitioners discussed 'listening to children' as a key value, and the nursery had received awards for recognising and supporting young children to express their views. Having spent some time in the nursery for a previous piece of research, I was familiar with some of the ways that participation was negotiated in practice. At Castle Nursery, children's participation challenged the status quo of traditional child-adult relationships, making the nursery a rich setting to explore for the research.

Participants in the study included young children from six months to 5 years old, as well as adult practitioners. As a later section of this paper will discuss, the children and practitioners were divided into two age-based groups with their own playrooms. During the fieldwork, I moved between spaces at the nursery, working with children and practitioners from both groups. In order to capture patterns and variations at the nursery, I tried to split my time evenly between the two age-based groups of children and practitioners, alternating when I went to each group so that I could observe at different times of the day. However, as the paper describes, there was a great deal of intermixing between the groups.

This research focused on how participation was 'lived' in a formal early learning and childcare institution - a field where I have over a decade of professional experience. To help unpick the ways that my professional background, teacher education, and more general socio-cultural orientations toward childhood influenced my thinking in the project, I incorporated a reflexive approach (Rose 1997; Finlay 2002; Berger 2015) I particularly engaged with Finlay's (2002) typology, specifically: reflexivity as introspection, in which the researcher probes his or her own personal experiences and meanings; reflexivity as intersubjective reflection, in which the researcher focuses on how unconscious processes, such as emotional responses, structure the relationships 
between researcher and participants, and reflexivity as social critique, in which the researcher foregrounds tensions around power, voice and silence between researcher and participants. In this paper, my own positionality is not the focus but does play a role in the analysis, and has therefore, at times, been explicitly written into the narrative. More on how the theory and practice of reflexivity were woven into this work can be found in separate writing ([Author Name] 2015).

\section{Making space for children's presence at Castle Nursery: policy, pedagogy and play}

In the Scottish context, policy and regulatory frameworks around early years create ambiguous 'imaginaries' of early childhood (Rosen 2015). For example, young children are framed as 'competent and active' (Education Scotland 2014), with practitioners urged to adopt a 'child-led' or 'child-centred' pedagogical approach, (Education Scotland 2014; Armstrong 2016) in which children's views are taken into account during everyday activities (Education Scotland 2014). However, there are also strands of Scottish early childhood policy that emphasise early childhood as a potential period of risk, where a 'weak foundation' can lead to future social problems(Deacon 2011, 9). Here, the young child is seen as both a potential threat and a potential redemptive agent (e.g. Moss and Petrie 2002). This risky discourse about young children leans heavily toward highlighting their future development, with less attention paid to their present lives.

Working within the ambiguous policy and practice spaces of early childhood education, Castle Nursery came firmly down on the side of children's participation. Children's 'ideas, thoughts, feelings, relationships and their physical bodies' (Bruce 2012, 13) were the driving force of daily life. Children's participation, as 'named' by adult practitioners, was not only about individualistic 'talking, thinking and deciding' 
(Alderson 2008, 79). Rather, children's contributions were seen to take place within entangled relationships with other people, places, materials, animals, sounds, and forces. Practitioners recognised the validity of these relationships, children's richness in creating and exploring them, and the need for time and space to do so.

Practitioners attributed the spark that compelled transformative change (Holt 2013) to the work of German educational philosopher Friedrich Froebel (1782-1852), whose ideas informed the nursery's pedagogical ethos. Froebel is known as the 'father of the kindergarten' - a key pioneer in early childhood education (Woodard 1979, 136; Bruce 2010). Today, Froebel's work is most often described in terms of principles, rather than specific prescriptive practices (Bruce 2012). Froebelian principles broadly include:

- The integrity of childhood in its own right;

- The relationship of every child to family, community and to nature, culture and society;

- The uniqueness of every child's capacity and potential;

- The holistic nature of the development of every child;

- The role of play and creativity as central integrating elements in development and learning;

- The right of children to protection from harm or abuse and to the promotion of their overall well-being.

(The Froebel Trust, no date)

An in-depth review and critique of Froebel's work is outside the scope of this paper. However, as the above principles illustrate, there is compatibility between a Froebelian approach and participatory intentions with young children. For example, a belief in the integrity of childhood as a period in its own right resonates with the literature on 
children's participation, where the child as competent social actor has been such a powerful idea (e.g. James 2011). Similarly, by recognising children's relationships with family, community, nature, culture and society, Froebelian principles resonate with discussions of children's participation as a relational practice (e.g. Mannion 2010).

\section{Transformations: challenging age-based hierarchy in daily life}

Gallacher (2005), in her social geography of a toddler playroom, notes that age was an organising factor in the setting, This way of organising space is in keeping with strong 'age and stage' beliefs in early years, that children need to be in differentiated spaces with different resources that are 'appropriate' for their age (e.g. Butin and Woolums 2009). On the surface, the spaces of Castle Nursery seemed organised by an age-and-stage view. The two main playrooms at the nursery were designated for the 'infants and toddlers' (from birth to three years old) and the 'pre-schoolers' (three to five years old). However, the way that children and practitioners actually lived in-andwith the spaces departed dramatically from the regimes of control that Gallacher (2005) describes.

Rather than stay in their designated playroom, children were encouraged and supported to move fluidly between spaces. Children could therefore take the lead regarding where they would like to spend their time and some seemed to take great delight in being in the 'wrong' space. For example, one day Naomi and Cerys ${ }^{2}$ - two children from the preschool room—spent the morning in the infant and toddler room. They initially giggled a little bit about being there, laughing to each other and saying,

\footnotetext{
${ }^{2}$ All names are pseudonyms.
} 
'We're babies now!' Soon, however, they settled into more serious play and even joined the infants and toddlers for gathering time.

A visiting teacher was in the infant and toddler space that day, and she later asked Maria, a practitioner, about why Naomi and Cerys had been there. Maria explained that children were free to visit other spaces, and that Naomi in particular had 'strong ties' to the infant and toddler room, because she had started at the nursery when she was quite young and had therefore spent a lot of time in that space. Maria's response demonstrated the ways that children's emotional lives and connections to spaces were recognised at the nursery - their status as full, respected partners walking alongside practitioners, rather than subordinates climbing an age-based ladder. Observing this interaction, I was transported back to my professional days, when teachers from the older groups would exile their students to my 'baby' room as a punishment: 'If you're going to act like a baby, you can go to the baby room'. In contrast, Maria welcomed Naomi and Cerys into the space - in fact, their presence seemed pleasing but unremarkable to her until the visitor pointed it out.

For me, coming from professional settings organised around age-based hierarchy, the transformations around adult-child relationships at Castle Nursery were sometimes difficult to stomach. On my first visit to the nursery, the movement between spaces and impossibility of surveilling each child at all times triggered a great deal of anxiety for me, and I left the nursery earlier than planned that day. Over time, however, I came to see the power of these practices in terms of transforming what it meant to be a child or adult in that institutional space.

Challenging age-based social hierarchy was not always easy for practitioners. It sometimes involved difficult conversations, resistance, and long processes of change. Over her lunch in the staff room, one practitioner described a time several years before, 
when a group of practitioners had done a Froebel training course together, which sparked deep contemplations about their work at the nursery. Over time, the discussions led to changes that brought practices more in line with the practitioners' participatory values. For example, at that time, children were expected to formally choose where they wanted to play, and 'sign in' to the garden space, with a limited number of children being allowed outside at any given time. Some practitioners felt that this was too adultcontrolled and was limiting children's ability to make their own choices. Others felt that the garden space needed to be carefully monitored and that having too many children at one time would be dangerous. Over the course of many months of discussion, the regulations around the garden space were relaxed so that children could move in and out more fluidly. This meant that staff also had to move fluidly and communicate with each other in new ways so that the garden space and indoor spaces could be supported. The change created opportunities for conversations with children themselves about safety, and the chance for children to manage their own play in the garden without direct adult control. The journey of relinquishing control was not always 'an easy road', the practitioner said. The process of change was sometimes uncomfortable. However, no matter how uncomfortable it could be at times, she considered a reflective approach to be an important element of her work at Castle Nursery.

As this example illustrates, both children and practitioners at the nursery were understood as 'beings in the process of becoming' (Freire 1970, 65)—with learning and education as ongoing, lifelong processes. Emphasising that adults are also learners resonates with ideas from childhood studies that trouble the 'finished' state of adulthood (Lee 2001). Practitioners were open to learning from children, as illustrated by the following example: 
Joanne, a practitioner, was in the garden with Claire, a child from the preschool room who was around four years old, and her little sister Rose Sally. Joanne asked Claire, 'Rose Sally is very tired this morning! Did she sleep last night? I wonder if she is not feeling well.'

Claire said yes, Rose Sally had slept just fine. Joanne noted that Rose Sally had not eaten much for morning snack, which was unusual, and asked Claire, 'Did she have breakfast? I wonder if she is ill.' Claire thought again and said that yes, Rose Sally had eaten a large breakfast. Accepting this information, which contradicted her own theory, Joanne replied 'Well, that explains why she wasn't hungry this morning.'

As Alderson $(2008,138)$ notes, young children may not be included in participation initiatives because their views are considered 'unreliable' or not sensible. In this example, in contrast, Joanne explicitly sought Claire's input—suggesting that Joanne recognised her own limited knowledge of Rose Sally's experiences, and drew on Claire's wider scope for understanding (Clark and Moss 2011).

\section{Age and life experience as a troublesome area for participation: the example of care routines}

The preceding sections have suggested that age was not a central organising principle at Castle Nursery. However, age-based difference was not completely dissolved. For example, the terms 'babies', 'wee ones', and 'little ones' were frequently used by both children and practitioners to describe the infants and toddlers, as was the term 'big ones' to refer to the older children. This discursive differentiation was affectionate, but did serve to draw distinctions between age-based groups of children. 
Intertwined with language, being a 'little one' also had a material impact on children's daily experiences, and on the ways that their agency and participation were shaped. This was particularly visible in the way babies and toddlers moved between spaces. While older children were able to open the doors between spaces and therefore move fluidly around the nursery, doors were a 'hard' barrier for the infants and toddlers, who were generally not tall or strong enough to open them. Notably, the doors were not propped open in the name of equal participation for the babies and toddlers. A practitioner explained that these spatial restrictions were about safety-particularly in the case of children who got around by crawling or bottom-shuffling. These children were lower to the ground, less visible, and therefore more likely to be stepped on or be struck by the very doors that created the barrier in the first place. Here, very young children's vulnerability was discussed in a way that was rare to hear about the older children, and there were limitations put in place on their movements accordingly.

As this example suggests, while chronological age was not used as a strict 'marker' of status at the nursery, it was an area of consideration--subtly intertwined with practitioners' interpretations of children's biological maturity and perceived (physical) vulnerabilities. Age could be therefore usefully be understood as a troublesome area at the nursery — an area of practice that required inquiry and reflection, and which particularly produced tensions, uncertainties, and questions about young children's participation. One particular way that age emerged as troublesome was in the negotiation of care routines at the nursery. For example, one afternoon, a child called Lily experienced great frustration when a nappy change interfered with her desire to go outside. She had joined a group of children who were going to the garden, but the practitioner going with them noticed that Lily's nappy was soiled. The practitioner gently blocked Lily's way, crouched down, and said to her, 'Lily, I think your nappy 
needs done.' Straightening up, the practitioner assured Lily that she could come outside as soon as her nappy was changed.

This explanation did not stop Lily from feeling unhappy about being left behind. As the door closed behind the group who had gone outside, Lily shouted, 'Ga-den!' at the remaining practitioners with increasing frustration. One of them came over to her and explained that she could go to the garden after having her nappy changed: 'We don't want you to get a sore bottom!' Lily was not mollified. She responded by shouting, 'Ga-den!' angrily and shaking her head, reaching for the door handle. At this point, a third practitioner - the one who was actually doing the nappy changes - came over. Reaching down toward Lily, she said, 'Let's get your nappy done so you can go outside'. Lily took her hand, and the practitioner led her to the nappy changing area. As soon as the nappy change was finished, Lily was taken outside to join the others.

Children's sleeping arrangements were another area of care where adults were not willing to relinquish control entirely to young children. Sleep routines were flexible and tailored to the individual child - there was not a universal 'rest time' when all children were expected to be sleeping. Similarly, decisions about where to sleep were usually made by the children: in the dedicated sleep room, which was a small room with cots, separated from the main playroom space, or children could sleep in their buggies, usually in the garden. In keeping with general practices at the nursery, practitioners tried to follow the children's preferences about where to sleep. However, conflict about sleep arose one afternoon, just after lunch, when Mary, a practitioner, came out of the sleep room holding Fergus, who was crying.

Red-faced and sweaty, Fergus clung to Mary, who soothed him while looking quite distressed herself. She went over to Sandra, another practitioner, and explained the situation. Fergus's parents were concerned that he was not sleeping well enough at 
nursery because he usually slept in his buggy. That morning at dropoff, his mother had requested that he sleep in a cot in the sleep room instead. However, Fergus himself did not seem to agree with this decision; he had stayed awake in the sleep room, crying and waking up the other children despite Mary's efforts to soothe him to sleep. Now the practitioner was not sure whose wishes to respect.

Sandra, the second practitioner, seemed equally conflicted about what to do. She thought it through out loud, saying 'No, I don't know...he wants to be in his buggy, but Mum and Dad want him in a cot...it's so hard when this happens.' Using a hopeful tone of voice, she asked Fergus if he wanted to sleep in a cot, explaining that 'Mummy and Daddy think you'll sleep really well'. This did not convince Fergus; he wailed, 'Noooooooo!' and began crying again. Eventually the two practitioners decided that some sleep was better than no sleep, and asked Fergus if he wanted to sleep in his buggy. He agreed, but was so agitated that he was not able to relax. He ended up staying awake and was brought back into the playroom - going on to have an afternoon where he seemed very tired.

Both of these examples illustrate a clash in priorities between children and practitioners. As Dahlberg and Moss $(2005,92)$ have argued, the 'care' element of early learning and childcare can be understood as an ethic that foregrounds 'attentiveness, responsibility, competence and responsiveness to the Other.' Bath (2013) also explicitly connects an ethic of care to an ethic of listening to children. In Fergus's case in particular, practitioners seemed to be pulled in multiple directions. Both Mary and Sandra seemed distressed by the situation-it seemed that they would have preferred to listen to Fergus and let him sleep in a buggy. However, they also seemed to feel obligated to meet his parents' expectations that he would sleep in a cot. Sandra's comment that 'It's so hard when this happens' suggests that Fergus's case was not the 
first time that practitioners felt torn between parents' and children's wishes. Though implicit, young children's limited life experience seemed to be at play, both in decisionmaking about nappy changing and sleeping. Practitioners seemed less confident in children's own knowledge and beliefs about 'what was good for them' than they did in other situations.

\section{Discussion}

This study of Castle Nursery focuses on how age-based hierarchies were transformed yet remained troublesome - in early childhood, but has a wider resonance regarding lessons, insights, and possibilities for other contexts (Mason 2002). In this section, I will focus on three main arguments regarding participatory work with children and young people.

First, that deconstruction of hierarchical beliefs about adults/children and adulthood/childhood was a fundamental element of participatory work. This was immediately visible in the ways that spaces and time were organised. Children's experiences in educational institutions may more typically be shaped by strict rules about the use of time, spaces and appropriate activities (e.g. Gallacher [2005] on battles for control in the nursery; Harden [2012] on 'good sitting, looking and listening'; Corsaro [2014] on children's 'secondary adjustments'). Children's own ideas, thoughts, feelings, and relationships may take a backseat to institutional arrangements that shape daily life toward homogenous and universal experiences (Yelland 2010).

The intentions behind this advice about adult control is usually couched in benevolent terms - a daily routine is said to reduce children's anxiety about the unknown (e.g. Markham, 2014; Zero to Three, 2014). However, there is undoubtedly a controlling effect, as adults try to structure and manage children's experiences. At 
Castle Nursery, in contrast, practitioners created opportunities for children to take the lead, focusing on children's richness and capabilities. Daily life was driven by children's 'presence' - their voices, agency and contributions — rather than by adult control. The ways of being a child at nursery (to be controlled) and an adult (to be controlling) were shifted into more equitable, jointly negotiated relations.

Second, that in order to transform hierarchical beliefs, reflective practice and dialogue was essential—practitioners being willing to engage in 'questioning and changing work assumptions and attitudes' (Bolton 2014, 10). This sometimes involved specific learning opportunities, such as the Froebel CPD course, and at other times arose from a more informal feeling that something at the nursery 'wasn't right'. Reflective practice requires engagement with political, social and cultural structures (Bolton 2014), and in the case of Castle Nursery, practitioners' reflective work was directed toward 'living' their participatory principles more fully. This, once again, required them to question the nature and utility of hierarchy and the child/adult binary (e.g. Lee, 2001; Prout, 2011; Leonard, 2016). For example, as Joanne and Claire's story shows, practitioners learned from children and treated children as a trusted source of information.

Through reflective practice, practitioners at Castle Nursery seemed to have developed a hybrid view of children as learners, but also as beings in the here-andnow-children were seen as respected fellow human beings in the world. Adults were similarly understood as 'emergent becomings' —-always-unfinished subjects-in-themaking' (Gallacher and Gallagher 2008, 509). However, to highlight practitioners' hybrid view of childhood and adulthood is not to gloss over the difficulty of reflective practice that engaged with deeper structural issues. Proponents of children's participation have been critiqued for portraying participation as a 'bland' and 'cosy' 
process (Woodhead 2010, xxii), with Cairns $(2006,218)$ noting that participation projects are often 'uncritically accepted as making a positive contribution'. Practitioners at Castle Nursery frequently described the difficulties, tensions and resentments that change could entail.

Finally, the paper has argued that despite attempts to transform adult-child hierarchies, age and life experience remained a troublesome area for participatory work with children and young people. Though chronological age as a 'neutral' marker of human development has been challenged, particularly in the field of childhood studies, very young children's biological immaturity and shorter period of life experience did create limitations for adults seeking to work in participatory ways. Looking at care practices, in Lily's case, the decision to over-ride her wishes was attributed to threats to her health from staying in a soiled nappy (e.g. Atherton and Mills 2004)--a prediction that practitioners prioritized, but Lily herself found less important. In Fergus's case, a more convoluted web of personal relationships between practitioners, parents and children presented itself (e.g. Brooker 2010). However, much like Lily’s situation, practitioners enforced the perspective of adults about what was 'good' for Fergus (here, his parents), pushing Fergus's view to the margins.

As these examples illustrate, even with a strong ethos of participation — bringing children's voice, agency and contribution to the forefront of daily life-there were times when adults decided that they knew best. The web of interdependent relationships in which participatory work happens includes the broader policy and regulatory context of ELC: for example, standards of care (Care Inspectorate 2017) and the ambiguous positioning of practitioners as service providers and parents as consumers (Moss 2017). The examples with Lily and Fergus therefore illuminate the ongoing ambiguities and uncertainties of trying to 'undo' generational positioning, particularly in institutional 
contexts that are more typically structured by adult control and shaped by top-down regulation.

\section{Conclusion}

This paper has traced some of the ways that participatory work with young children was 'lived' in the context of daily life in one early childhood setting. Rather than present adults uncritically as 'oppressors' of children, or for children to be framed as acting as independent 'agents of their own destiny' (Mannion 2007, 413) this paper has framed children's participation as 'lived' through relationships between adults and children. In particular, the paper looks at how early childhood practitioners attempted to transform age-based hierarchies in order to put children's voice, contribution and agency at the forefront of daily life and routines. Avoiding a reproduction of the 'hegemony of nice' that plagues the early childhood field (Goldstein 1998) this paper has drawn out some of the messier lived experiences of daily practice.

The paper has described the ways that children's strong presence was felt in spatial and temporal routines, as well as in the ways that practitioners treated young children as respected fellow 'emergent becomings' in the world. Practitioner resistance to more traditional patterns of domination and control created an institutional space in which child/adult relations were 'played out otherwise' (Holt 2013, 657). However, despite the efforts to blur the adult/child binary, age and life experience did remain a troublesome area for practitioners and children. Care practices, such as nappy changing and sleep routines, seemed to particularly create barriers and tensions to the project of 'undoing' generational hierarchy. Though the early learning and childcare institution may seem like a bounded place, it is connected to wider social, cultural, and political contexts on a variety of scales (Holt 2013). It is within these interconnections that 
children's participation is negotiated and brought into practice. Children's participation itself can usefully be seen as a troublesome area of theory, research and practice, where many facets of identity, experience and material differences interact. Participatory work with children must therefore be maintained as a space for inquiry, reflection and uncertainty.

Acknowledgements: The author would like to acknowledge the children and staff at Castle Nursery, who made this project possible, Professor Kay Tisdall and Professor John Davis, for their support during the research, as well as the editors and anonymous reviewers for their comments and feedback. This research was supported by scholarship awards from the University of Edinburgh.

\section{References}

Alderson, Priscilla. 2008. Young Children's Rights: Exploring Beliefs, Principles and Practice. 2nd ed. London: Jessica Kingsley Publishers. 2010. "Younger Children's Individual Participation in 'All Matters Affecting the Child."' In A Handbook of Children and Young People's Participation: Perspectices from Theory and Practice, edited by Barry Percy-Smith and Nigel Thomas, 88-98. London: Routledge. . 2012. "Young Children's Human Rights: A Sociological Analysis." The International Journal of Children's Rights 20 (2): 177-98. https://doi.org/10.1163/157181812X622187.

Alderson, Priscilla, Joanna Hawthorne, and Margaret Killen. 2005. "The Participation Rights of Premature Babies.” The International Journal of Children's Rights 13: $31-50$.

Armstrong, Heather. 2016. "Inspiring Adults Month: Our Children Need Creative Adults." Arts from the Start 2016. 2016. https://artsfromthestart.org/2016/03/01/inspiring-adults-month-our-childrenneed-creative-adults/.

Bae, Berit. 2012. "Children and Teachers as Partners in Communication: Focus on Spacious and Narrow Interactional Patterns." International Journal of Early Childhood 44 (1): 53-69. https://doi.org/10.1007/s13158-012-0052-3.

Bath, Caroline. 2013. "Conceptualising Listening to Children as an Ethic of Care in Early Childhood Education and Care." Children \& Society 27 (5): 361-71. https://doi.org/10.1111/j.1099-0860.2011.00407.x.

Bath, Caroline, and Rauni Karlsson. 2016. "The Ignored Citizen: Young Children's Subjectivities in Swedish and English Early Childhood Education Settings." Childhood 23 (4): 554-65. https://doi.org/10.1177/0907568216631025.

Berger, Roni. 2015. 'Now I See It, Now I Don't: Researcher's Position and Reflexivity in Qualitative Research." Qualitative Research 15 (2): 219-34. https://doi.org/10.1177/1468794112468475. 
[AUTHOR NAME] 2015. "Putting Reflexivity into Practice: Experiences from Ethnographic Fieldwork." Ethics and Social Welfare 9 (1): 83-91.

Bolton, Gillie. 2014. Reflective Practice: Writing and Professional Development. 4th ed. Los Angeles: SAGE.

Brooker, Liz. 2010. "Constructing the Triangle of Care: Power and Professionalism in Practitioner/Parent Relationships." British Journal of Educational Studies 58 (2): 181-196. https://doi.org/10.1080/00071001003752203.

Bruce, Tina. 2010. "Theory, Practice and Context." In Early Childhood: A Guide for Students, edited by Tina Bruce, 53-59. . 2012. "The Whole Child." In Early Childhood Practice: Froebel Today, edited by Bruce, Tina, 5-16. London: SAGE Publications.

Butin, Dan, and Jennifer Woolums. 2009. "Early Childhood Centers." http://www.ncef.org/pubs/earlychild.pdf.

Cairns, Liam. 2006. "Participation with Purpose." In Children, Young People and Social Inclusion: Participation for What?, edited by E. Kay M. Tisdall, John M. Davis, Malcolm Hill, and Alan Prout, 217-34. Bristol: Policy Press.

Care Inspectorate. 2017. "Health and Social Care Standards: My Support, My Life." http://www.newcarestandards.scot/.

Clark, Alison. 2007. "Views from inside the Shed: Young Children's Perspectives of the Outdoor Environment." Education 3-13 35 (4): 349-63. https://doi.org/10.1080/03004270701602483.

Clark, Alison, Anne Trine Kjorholt, and Peter Moss, eds. 2005. Beyond Listening: Children's Perspectives on Early Childhood Services. Bristol: The Policy Press.

Clark, Alison, Susan McQuail, and Peter Moss. 2003. Exploring the Field of Listening to and Consulting with Young Children. Department for Education and Skills. https://www.education.gov.uk/publications/standard/publicationDetail/Page1/R B445.

Clark, Alison, and Peter Moss. 2011. Listening to Young Children: The Mosaic Approach. 2nd ed. London: National Children's Bureau.

Clark, Alison, and June Statham. 2005. "Listening to Young Children: Experts in Their Own Lives." Adoption \& Fostering Journal 29 (1): 45-56.

Corsaro, William A. 2014. The Sociology of Childhood. 4th ed. Thousand Oaks, Calif.: Pine Forge Press.

Dahlberg, Gunilla, and Peter Moss. 2005. Ethics and Politics in Early Childhood Education. London: Routledge Falmer.

Deacon, Susan. 2011. "Joining the Dots: A Better Start for Scotland's Children." Edinburgh: Scottish Government. http://www.gov.scot/Publications/2011/03/02093147/0.

Education Scotland. 2014. "Building the Ambition: National Practice Guidance on Early Learning and Childcare." 2014. http://www.educationscotland.gov.uk/learningandteaching/earlylearningandchild care/buildingtheambition/index.asp.

Emilson, Anette, and Anne-Mari Folkesson. 2006. "Children's Participation and Teacher Control." Early Child Development and Care 176 (3-4): 219-38. https://doi.org/10.1080/03004430500039846.

Esser, Florian, Meike S. Baader, Tanja Betz, and Beatrice Hungerland. 2016. Reconceptualising Agency and Childhood: New Perspectives in Childhood Studies. Routledge. 
Ferholt, Beth, and Anna Pauliina Rainio. 2016. "Teacher Support of Student Engagement in Early Childhood: Embracing Ambivalence through Playworlds." Early Years 0 (0): 1-13. https://doi.org/10.1080/09575146.2016.1141395.

Finlay, Linda. 2002. "Negotiating the Swamp: The Opportunity and Challenge of Reflexivity in Research Practice." Qualitative Research 2 (2): 209-30. https://doi.org/10.1177/146879410200200205.

Freire, Paulo. 1970. Pedagogy of the Oppressed. London: The Penguin Group. Gallacher, Lesley. 2005. “"The Terrible Twos': Gaining Control in the Nursery?" Children's Geographies 3 (2): 243-64. https://doi.org/10.1080/14733280500161677.

Gallacher, Lesley, and Michael Gallagher. 2008. "Methodological Immaturity in Childhood Research?: Thinking Through 'Participatory Methods'." Childhood 15 (4): 499-516. https://doi.org/10.1177/0907568208091672.

Gallagher, Michael. 2005. "Producing the Schooled Subject: Techniques of Power in a Primary School." Edinburgh: University of Edinburgh. https://www.era.lib.ed.ac.uk/handle/1842/7260. . 2008. "'Power Is Not an Evil': Rethinking Power in Participatory Methods." Children's Geographies 6 (2): 137-50. https://doi.org/10.1080/14733280801963045.

Ghirotto, Luca, and Valentina Mazzoni. 2014. "Being Part, Being Involved: The Adult's Role and Child Participation in an Early Childhood Learning Context." International Journal of Early Years Education 21 (4): 300-308. https://doi.org/10.1080/09669760.2013.867166.

Goldstein, Lisa S. 1998. "More than Gentle Smiles and Warm Hugs: Applying the Ethic of Care to Early Childhood Education." Journal of Research in Childhood Education 12 (2): 244-61. https://doi.org/10.1080/02568549809594888.

Harden, Jeni. 2012. "Good Sitting, Looking and Listening: The Regulation of Young Children's Emotions in the Classroom." Children's Geographies 10 (1): 83-93.

Holloway, Sarah L., and Helena Pimlott-Wilson. 2011. "Geographies of Children, Youth and Families: Defining Achievements, Debating the Agenda." In Geographies of Children, Youth and Families: An International Perspective, edited by Louise Holt, 9-24. London: Routledge.

Holloway, Sarah L., and Gill Valentine. 2000. "Children's Geographies and the New Social Studies of Childhood.” In Children's Geographies: Playing, Living, Learning, edited by Sarah L. Holloway and Gill Valentine. Abingdon: Routledge.

Holt, Louise. 2013. "Exploring the Emergence of the Subject in Power: Infant Geographies." Environment and Planning D: Society and Space 31 (4): 645663. https://doi.org/10.1068/d12711.

James, Allison. 2011. "Agency." In The Palgrave Handbook of Childhood Studies, edited by Jens Qvortrup, William A. Corsaro, and Michel Honig, 34-45. Basingstoke: Palgrave MacMillan.

Johansson, Eva, and Anette Emilson. 2010. "Toddlers Life in Swedish Preschool." International Journal of Early Childhood 42 (2): 165-79. https://doi.org/10.1007/s13158-010-0017-3.

Kraftl, Peter, John Horton, and Faith Tucker. 2012a. "Concluding Reflections: What next and Where next for Critical Geographies of Youth Policy and Practice?" In Critical Geographies of Childhood and Youth: Contemporary Policy and Practice, edited by Peter Kraftl, John Horton, and Faith Tucker, 265-69. Policy Press Scholarship Online. 
http://policypress.universitypressscholarship.com/view/10.1332/policypress/978 1847428462.001.0001/upso-9781847428462-chapter-16.

.2012b. "Editors' Introduction: Critical Geographies of Childhood and Youth."

In Critical Geographies of Childhood and Youth: Contemporary Policy and

Practice, edited by Peter Kraftl, John Horton, and Faith Tucker, 1-21. Policy

Press Scholarship Online.

http://policypress.universitypressscholarship.com/view/10.1332/policypress/978

1847428462.001.0001/upso-9781847428462-chapter-1.

Lansdown, Gerison. 2005a. Can You Hear Me? The Right of Young Children to

Participate in Decisions Affecting Them. Vol. 36. The Hague: Bernard van Leer

Foundation. http://eric.ed.gov/?id=ED522740.

- 2005b. The Evolving Capacities of the Child. Innocenti Insight 11. Florence:

UNICEF: Innocenti Research Centre. https://www.unicef-

irc.org/publications/384.

Le Borgne, Carine, and E. Kay M. Tisdall. 2017. “Children's Participation: Questioning Competence and Competencies?" Social Inclusion 5 (3).

Lee, Nick. 2001. Childhood and Society: Growing up in an Age of Uncertainty. Maidenhead: Open University Press.

Leonard, Madeleine. 2016. The Sociology of Children, Childhood and Generation. London: SAGE.

MacNaughton, Glenda, Patrick Hughes, and Kylie Smith. 2007. "Early Childhood Professionals and Children's Rights: Tensions and Possibilities around the United Nations General Comment No. 7 on Childrens Rights." International Journal of Early Years Education 15 (2): 161-70. https://doi.org/10.1080/09669760701288716. . 2008. Young Children as Active Citizens: Principles, Policies and Pedagogies. Newcastle: Cambridge Scholars Publishing.

Malone, K., and C. Hartung. 2010. "Challenges of Participatory Practice with Children." In A Handbook of Children and Young People's Participation: Perspectives from Theory and Practice, edited by Barry Percy-Smith and Nigel Thomas. London: Routledge.

Mannion, Greg. 2007. "Going Spatial, Going Relational: Why 'Listening to Children' and Children's Participation Needs Reframing." Discourse: Studies in the Cultural Politics of Education 28 (3): 405-20. https://doi.org/10.1080/01596300701458970. . 2010. "After Participation: The Socio-Spatial Performance of Intergenerational Becoming." In A Handbook of Children and Young People's Participation: Perspectives from Theory and Practice, edited by Barry Percy-Smith and Nigel Thomas. London: Routledge.

Markham, Laura. 2014. "Structure: Why Kids Need Routines." 2014. http://www.ahaparenting.com/parenting-tools/family-life/structure-routines.

Mason, Jennifer. 2002. Qualitative Researching. London: SAGE Publications.

Mayall, Berry. 2002. Towards a Sociology for Childhood: Thinking from Children's Lives. Buckingham: Open University Press. . 2006a. "Child-Adult Relations in Social Space.” In Children, Young People and Social Inclusion: Participation for What?, edited by E. Kay M. Tisdall, John M. Davis, Malcolm Hill, and Alan Prout, 199-216. Bristol: Policy Press. 2006b. "Values and Assumptions Underpinning Policy for Children and Young People in England." Children's Geographies 4 (1): 9-17. https://doi.org/10.1080/14733280600576923. 
Moosa-Mitha, Mehmoona. 2005. "A Difference-Centred Alternative to Theorization of Children's Citizenship Rights." Citizenship Studies 9 (4): 369-88. https://doi.org/10.1080/13621020500211354.

Moss, Peter. 2017. "Power and Resistance in Early Childhood Education: From Dominant Discourse to Democratic Experimentalism." Journal of Pedagogy Pedagogický Časopis 8 (September): 11-32. https://doi.org/10.1515/jped-20170001.

Moss, Peter, and Pat Petrie. 2002. From Children's Services to Children's Spaces: Public Policy, Children and Childhood. London: Routledge Falmer.

Oswell, David. 2016. "Re-Aligning Children's Agency and Re-Socialising Children in Childhood Studies." In Reconceptualising Agency and Childhood: New Perspectives in Childhood Studies, edited by Florian Esser, Meike S. Baader, Tanja Betz, and Beatrice Hungerland, 32-44. Abingdon: Routledge.

Percy-Smith, Barry. 2010. "Councils, Consultations and Community: Rethinking the Spaces for Children and Young People's Participation1." Children's Geographies 8 (2): 107-22. https://doi.org/10.1080/14733281003691368.

Prout, Alan. 2011. "Taking a Step Away from Modernity: Reconsidering the New Sociology of Childhood." Global Studies of Childhood 1 (1): 4. https://doi.org/10.2304/gsch.2011.1.1.4.

Rose, Gillian. 1997. "Situating Knowledges: Positionality, Reflexivities and Other Tactics." Progress in Human Geography 21 (3): 305-20. https://doi.org/10.1191/030913297673302122.

Rosen, Rachel. 2015. "Children's Violently Themed Play and Adult Imaginaries of Childhood: A Bakhtinian Analysis." International Journal of Early Childhood 47 (2): 235-50.

Simpson, Donald, Sandra Loughran, Eunice Lumsden, Philip Mazzocco, Rory McDowall Clark, and Christian Winterbottom. 2017. "'Seen but Not Heard'. Practitioners Work with Poverty and the Organising out of Disadvantaged Children's Voices and Participation in the Early Years." European Early Childhood Education Research Journal 25 (2): 177-88. https://doi.org/10.1080/1350293X.2017.1288014.

The Froebel Trust. no date. "Froebel Today." no date. http://www.froebel.org.uk/froebel-in-the-21st-century/.

The Scottish Government. 2014. Building the Ambition: National Practice Guidance on Early Learning and Childcare: Children and Young People (Scotland) Act 2014. Edinburgh: The Scottish Governmetn.

Tisdall, E. Kay M. 2013. "The Transformation of Participation? Exploring the Potential of 'Transformative Participation' for Theory and Practice around Children and Young People's Participation." Global Studies of Childhood 3 (2): 183. https://doi.org/10.2304/gsch.2013.3.2.183. . 2015. "Children and Young People's Participation: A Critical Consideration of Article 12." In Routledge International Handbook of Children's Rights Studies, edited by Wouter Vandenhole, Ellen Desmet, Didier Reynaert, and Sara Lembrechts, 185-200. Abingdon: Routledge.

UN Committee on the Rights of the Child. 2005. General Comment No. 7 (2005): Implementing Child Rights in Early Childhood. Office of the UN High Commissioner for Human Rights.

http://tbinternet.ohchr.org/_layouts/treatybodyexternal/Download.aspx?symboln $\mathrm{o}=\mathrm{CRC} \% 2 \mathrm{fC} \% 2 \mathrm{fGC} \% 2 \mathrm{f} 7 \% 2 \mathrm{fRev} .1 \& \mathrm{Lang}=\mathrm{en}$. 
Woodard, Carol. 1979. "Gifts from the Father of the Kindergarten." The Elementary School Journal 79 (3): 136-41.

Woodhead, Martin. 2010. "Foreword." In A Handbook of Children and Young People's Participation: Perspectives from Theory and Practice, edited by Barry PercySmith and Nigel Thomas, xiv-xxii. Abingdon: Routledge.

Wyness, Michael. 2015. Childhood. Cambridge: Polity Press.

Yelland, Nicola. 2010. "Extending Possibilities and Practices in Early Childhood Education." In Contemporary Perspectives on Early Childhood Education, edited by Nicola Yelland, 3-13. Maidenhead: Open University Press.

Zero to Three. 2014. "Love, Learning, and Routines." 2014. http://www.zerotothree.org/child-development/social-emotionaldevelopment/love-learning-and-routines.html. 